\title{
Tracheobronchial and Alveolar Particle Surface Area Doses in Smokers
}

\author{
Fernanda Carmen Fuoco ${ }^{1, *}$, Luca Stabile ${ }^{1}$, Giorgio Buonanno ${ }^{1,2}$, Mauro Scungio ${ }^{1}$, \\ Maurizio Manigrasso ${ }^{3}$ and Andrea Frattolillo ${ }^{4}$ \\ 1 Department of Civil and Mechanical Engineering, University of Cassino and Southern Lazio, \\ via G. di Biasio 43, 03043 Cassino, Italy; 1.stabile@unicas.it (L.S.); buonanno@unicas.it (G.B.); \\ m.scungio@unicas.it (M.S.) \\ 2 Queensland University of Technology, 2 George St, Brisbane QLD 4000, Australia \\ 3 INAIL, Settore Ricerca, Certificazione e Verifica, via IV Novembre 144, 00187 Rome, Italy; \\ m.manigrasso@inail.it \\ 4 Department of Civil and Environmental Engineering and Architecture, University of Cagliari, \\ via Marengo 2, 09123 Cagliari, Italy; andrea.frattolillo@unica.it \\ * Correspondence: fc.fuoco@unicas.it \\ Academic Editor: Robert W. Talbot \\ Received: 29 November 2016; Accepted: 13 January 2017; Published: 19 January 2017
}

\begin{abstract}
Cigarette smoke is the main cause of lung cancer events. Mainstream cigarette smoke (MSS) is a direct concern for smokers, but also the secondhand smoke (SHS) contributes to the smoker exposure. In addition, smoker exposure is affected by the "free-smoke" particle exposure (B), related to the micro-environments where smokers spend time. The aim of this paper is to evaluate the daily alveolar and tracheobronchial deposited fractions of airborne particles for smokers as the sum of these three contributions: MSS, SHS, and B. Measurements of particle surface area distributions in the MSS were performed through a Scanning Mobility Particle Sizer, an Aerodynamic Particle Sizer, and a Thermo-dilution system on five types of conventional cigarettes. A Monte Carlo method was then applied to evaluate the most probable value of dose received during the inhalation of MSS by smokers. Measurements of particle concentrations in SHS and at the "free-smoke" particle background (B) were performed through 24-h monitoring at a personal scale of adult smoker through hand-held devices. This paper found that the total daily deposited dose for typical smokers was $1.03 \times 10^{5} \mathrm{~mm}^{2} \cdot$ day $^{-1}$. The main contribution of such a huge daily dose was addressable to the MSS $(98 \%)$ while SHS contributed $1.1 \%$, increasing up to $2 \%$ for people smoking only while traveling in a car.
\end{abstract}

Keywords: cigarette smoking; active smokers; particle dose; personal exposure; deposited surface area

\section{Introduction}

Aerosol exposure is a major environmental health concern due to the ability of particles to penetrate deeply into the respiratory system and cell membranes [1] and translocate from the airways into the blood circulation [2,3]. Particles are also able to deposit in secondary organs [4], including brain tissue [5] and to carry condensed toxic compounds [6-8].

The deposited particle surface area in the lung, defined in this paper as dose, has been identified as a relevant metric for particle exposure quantifications [9].

In assessing human exposure to airborne particles, cigarette smoking is of particular interest as it is the main cause of lung cancer events [10-23]. In fact, about $60 \%$ and $90 \%$ of lung cancer events for women and men, respectively, are related to cigarette smoking $[14,15,19]$. Such a high lung cancer risk is due to the physical-chemical characteristics of the mainstream cigarette smoke (MSS). In fact, the 
cigarette-generated particles contain more than 3500 semi-volatile and non-volatile compounds, some of them classified as carcinogenic such as hydrocarbons (PAHs; [24-27]), dioxins and furans [28], heavy metals [25,29-34], and tobacco-specific nitrosamines [25,31,35-37]. Moreover, in fresh unaged tobacco cigarette mainstream smoke particle concentrations of about $4 \times 10^{9}$ part cm $^{-3}$ were measured, with an arithmetic mean diameter of about $0.2 \mu \mathrm{m}$ [38-41].

Cigarette smoking affects not only active smokers (through the mainstream cigarette smoke) but also passive smokers are exposed to conventional cigarette second-hand smoke.

In particular, cigarette mainstream smoke (MSS) is the smoke emerging from the mouth end of a cigarette during puffing [36]. Mainstream smoke consists of an aerosol containing liquid droplets (particulate phase) suspended in the gas vapor phase, which is generated by overlapping burning, pyrolysis, pyrosynthesis, distillation, sublimation, and condensation processes [37]. Second-hand smoke (SHS) is the sidestream smoke emitted from the burning of the tip of a cigarette $[42,43]$ plus the smoke exhaled by active smokers. There are more than 3000 chemicals in SHS and more than 60 of them have been identified as toxicants or carcinogens $[15,40,44,45]$.

In assessing personal exposure of smokers to airborne particles, and in understanding smoking-related diseases, the different types of cigarette smokes (MSS and SHS) have to be considered since MSS and SHS aerosols require different experimental set-ups to be measured. The mainstream smoke is usually measured by a smoking machine able to simulate the human puff smoking behavior. Particle concentrations and size distributions of MSS have been investigated by numerous different researchers [46]. In general, fresh MSS has been found to have an average mode of the number size distribution that ranged between 184 and $212 \mathrm{~nm}$ particle concentrations on the order of $10^{9}$ part $^{-3}$ [41].

In order to evaluate the effect of cigarette smoke on non-smokers, it is common to measure the SHS. The SHS is usually detected by portable real-time airborne particle monitoring instruments which measure the air ambient particles (both indoors and outdoors).

Airborne particles comprise a significant portion of the sidestream and mainstream mass emissions from burning cigarettes and other tobacco products, and indoor particle concentrations associated with SHS are also substantial. The size range of SHS particles is approximately $0.02-2 \mu \mathrm{m}$, so that all of the SHS particles fall within the category of fine particulate matter $\left(\mathrm{PM}_{2.5}\right)$.

Based on the aforementioned evidence, SHS results are poorly estimated since it has been only evaluated as an environmental measurement and as a contribution to non-smokers' particle exposure. In fact, while data on the exposure of individuals living with people who smoke are available in literature [47], no data on the contribution of secondhand smoke on the smoker himself are available.

In addition, smoker exposure is also affected by the level of particle background related to the specific environment visited by smokers during the day, defined in this paper as "free-smoke" particle background (B). In fact, it is well known how particle exposure of humans can be affected by the type of environment or activities performed during the day (such as cooking, burning candles, traveling by car, etc. [48,49]).

In the light of the abovementioned aspects, the SHS and B could affect the active smokers' exposure, and as such, it needs to be considered in the assessment of the total daily particle exposure of smokers.

The main objectives of this work are: (i) to evaluate the daily particle (alveolar and tracheobronchial) deposited doses of active smokers due to the contribution of MSS and SHS; (ii) to determine the contributions of MSS, SHS, and B on the daily dose. To this purpose the dose received by typical male and female Italian smokers was evaluated on the basis of particle surface area measured in the cigarette mainstream and secondhand smoke aerosol, taking into account typical smoker lifestyle. A Monte Carlo method was applied to calculate dose values. 


\section{Material and Methods}

The daily (tracheobronchial and alveolar) deposited surface area doses (expressed as sum of alveolar and tracheobronchial contributions) received by a smoker during a day $\left(\Delta \mathrm{S}_{\mathrm{Alv}, \mathrm{TB}}\right)$ were evaluated as the sum of three contributions: mainstream smoke (MSS), secondhand smoke (SHS), and "free-smoke" particle background (B).

$$
\Delta \mathrm{S}_{\mathrm{Alv}, \mathrm{TB}_{\mathrm{Male} / \mathrm{Female}}}=\Delta \mathrm{S}_{\mathrm{Alv}_{\mathrm{TB}} \mathrm{TB}_{(\mathrm{MSS})}}+\Delta \mathrm{S}_{\mathrm{Alv}_{\mathrm{TB}} \mathrm{TB}_{(\mathrm{SHS})}}+\Delta \mathrm{S}_{\mathrm{Alv}, \mathrm{TB}_{(\mathrm{B})}}
$$

\subsection{Contribution of Mainstream Smoke Aerosol to the Daily Dose}

\subsubsection{Experimental Campaign}

Different types of tobacco cigarettes, as detailed in Table 1 were continuously tested. Measurements were performed in the European Accredited (EA) Laboratory of Industrial Measurements (LAMI) at the University of Cassino and Southern Lazio, Italy, during February-December 2015 in a 150- $\mathrm{m}^{3}$ room, where thermo-hygrometric conditions were continuously controlled and monitored in order to guarantee temperature and relative humidity values equal to $20 \pm 1{ }^{\circ} \mathrm{C}$ and $50 \% \pm 10 \%$, respectively.

Table 1. Characteristics of the selected tobacco cigarettes.

\begin{tabular}{cc}
\hline Sample & Nicotine Content (mg) \\
\hline Cigarette A & 0.6 \\
Cigarette B & 0.6 \\
Cigarette C & 0.8 \\
Cigarette D & 0.5 \\
Cigarette E & 0.6 \\
\hline
\end{tabular}

\subsubsection{Instrumentation and Particle Surface area Distributions Measurement}

In order to measure particle size distribution in the MSS of the cigarettes, several instruments were used:

- a Scanning Mobility Particle Sizer spectrometer, SMPS 3936 (TSI Inc., Shoreview, MN, USA), made up of an Electrostatic Classifier EC 3080 (TSI Inc.), used to classify the sampled particles in different channels according to their size, and a CPC 3775 (TSI Inc.) to count the particles of the selected size. The SMPS 3936 is able to measure particle surface area distribution in the range of $6-800 \mathrm{~nm}$ with a minimum time resolution of $120 \mathrm{~s}$;

- a TSI model 3321 Aerodynamic Particle Sizer (APS) spectrometer which is able to measure the surface area distribution of particles in the range $0.5-20 \mu \mathrm{m}$ through a time-of-flight technique with a one-second time resolution;

- a thermo-dilution system (two-step dilution) made up of a Rotating Disk Thermodiluter, RDTD (model 379020; Matter Engineering AG) [50] and a Thermal Conditioner Air Supply (model 379030; Matter Engineering AG) [51] which is able to ensure proper sample conditioning during cigarette-generated particle number distribution and total concentration measurements. Temperature control is also allowed in the thermodilution section by a built-in heater with selectable temperatures;

- a TSI model 4410 flow meter to check flow rates in the tubing connecting the cigarette to the measuring devices.

Particle size distributions were measured through the SMPS 3936-APS 3321 system. Sub-micron particle surface area distributions (through the SMPS) and super-micron particle surface area distributions (through the APS) were tested separately. In particular, 30 samplings for each instrument 
(SMPS, APS) were performed using the abovementioned cigarettes. A 135-s long sampling time was adopted for SMPS and APS. In particular, an aerosol/sheath flow ratio of $0.3 \mathrm{~L} \cdot \mathrm{min}^{-1} / 3 \mathrm{~L} \cdot \mathrm{min}^{-1}$ was selected for the SMPS, which then provided particle surface area distributions in the $14-700 \mathrm{~nm}$ mobility diameter range.

In order to test the mainstream aerosol, cigarettes were connected to the aerosol sampling line. In particular, before entering the instruments (SMPS or APS), the aerosol was passed through the thermo-dilution system to prevent measurement artifacts from potentially occurring during the sampling process [50,51]. In fact, cigarette-generated mainstream aerosols are highly concentrated and made up of volatile gaseous compounds that may condense, leading to either the possible formation of stable nuclei (nucleation) or the growth of existing particles (condensation). Therefore, it was necessary to properly dilute the aerosol through the thermo-dilution system to prevent particle size distributions quickly undergoing significant changes in the few seconds lasting between the aerosol sampling and its measurement [50-52]. The thermo-dilution system drew the mainstream aerosol from each cigarette's mouthpiece at a fixed flow rate of $1 \mathrm{~L} \cdot \mathrm{min}^{-1}$. Flow rates were checked through the Flow meter TSI 4410. The thermo-dilution system temperature was set at $37^{\circ} \mathrm{C}$ in order to simulate the respiratory apparatus. After the thermo-dilution process, the aerosol was passed through the SMPS (aerosol flow rate of $0.3 \mathrm{~L} \cdot \mathrm{min}^{-1}$ ), or the APS (aerosol flow rate of $1 \mathrm{~L} \cdot \mathrm{min}^{-1}$ ) depending on whether sub-micron or super-micron particle size distributions were measured. A dilution ratio equal to 1:1700 was chosen for all the instruments in order to avoid over-range measurements. Moreover, because of the long path experienced by the aerosol before entering the measurement devices, a diffusion loss correction was applied to estimate the particle losses onto the inner surface of the tubing. These corrections were calculated by applying the method proposed in Buonanno et al. (2012) [48]; further details about diffusion loss correction evaluation are reported in Buonanno et al. (2012) [52].

Particle surface area distributions over the entire measurement range $(14 \mathrm{~nm}-20 \mu \mathrm{m})$ were obtained by merging and fitting SMPS and APS values through the DataMerge ${ }^{\circledR}$ Software (TSI Inc.) through the approach reported by Shen et al. (2002) [53]. A particle density of $1.1 \mathrm{~g} \mathrm{~cm}^{-3}$ and a unit shape factor were applied for SMPS-APS distribution merging on the basis of the findings reported by Johnson et al. (2014) [54].

\subsubsection{Particle (Alveolar and Tracheobronchial) Deposited Doses in the MSS}

The daily deposited doses received by a smoker in the mainstream cigarette aerosol $\left(\Delta \mathrm{S}_{\mathrm{Alv}, \mathrm{TB}}\right)$, were evaluated in terms of particle deposited surface area concentration for males and females as follows [55,56]:

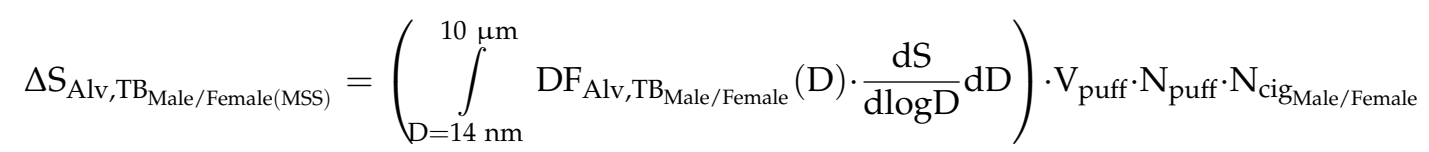

where $V_{\text {puff }}\left(\mathrm{cm}^{3}\right)$ is the puff volume, $\mathrm{dS} / \mathrm{d} \log \mathrm{D}\left(\mu \mathrm{m}^{2} \cdot \mathrm{cm}^{-3}\right)$ refers the particle surface area concentrations of a certain particle diameter (D) received for each puff of mainstream cigarette aerosol, $\mathrm{N}_{\text {puff }}$ (puffs/cigarette) is the puffs number per cigarette, $\mathrm{N}_{\text {cig }}$ (cigarette/day) represents the cigarette consumption per day, and $\mathrm{DF}_{\mathrm{Alv}, \mathrm{TB}}$ represents the deposition fraction in the alveolar and tracheobronchial regions of the lungs, as a function of the particle diameter (D), as adapted from the International Commission on Radiological Protection [57]. DF values were considered for adult males and females performing a sitting activity. Available average data of cigarette consumption among Italian adults, obtained from Istituto Superiore di Sanità [58], reported 14.1 and 11.8 as the number of cigarettes smoked per day for males and females, respectively. A summary of the average data of human smoking patterns, obtained on the basis of a detailed scientific literature analysis performed by Zacny and Stitzer [59], is provided in Table 2. Data were reported as mean value \pm standard deviation since they were checked for normality applying a Shapiro-Wilk test. 
Table 2. Average data of human smoking patterns summarized by Zacny and Stitzer [59].

\begin{tabular}{ccc}
\hline Puff Volume, $\mathbf{V}_{\text {puff }}\left(\mathrm{cm}^{3}\right)$ & Puffs per Cigarette, $\mathbf{N}_{\text {puff }}$ & Puff Time, $\mathbf{t}_{\text {puff }}(\mathbf{s})$ \\
\hline $42.5 \pm 9.3$ & $11.5 \pm 2.2$ & $1.8 \pm 0.4$ \\
\hline
\end{tabular}

Dose values were calculated through the abovementioned Equation (2) by applying a Monte Carlo method [60]. In particular, deposited particle surface area concentrations were expressed as most probable values and 5th-95th intervals.

\subsection{Contribution of Secondhand Smoke Aerosol and "Free-Smoke" Particle Background to the Daily Dose}

\subsubsection{Experimental Campaign}

In order to detect particle concentrations in the secondhand smoke aerosol and at "free-smoke" particle background, personal monitoring campaigns were performed. A 24-h monitoring in terms of (alveolar and tracheobronchial) deposited surface area concentration was performed by smoker adults, mainly students, aged between 25-35 years. A total of 20 adults were involved in the campaign. The experimental campaign was carried out in Cassino, Central Italy $\left(41^{\circ} 30^{\prime} 0^{\prime \prime} \mathrm{N}-13^{\circ} 50^{\prime} 0^{\prime \prime} \mathrm{E}\right)$ during February-December 2015. Adults were asked to lead their normal life.

\subsubsection{Instrumentation and Particle Surface Area Distributions Measurement}

The mobile experimental apparatus was composed of two hand-held UFP counters (NanoTracer, Philips, Amsterdam, The Netherlands). This device works by diffusion charging: an electrometer measures the number particle concentration by means of the current induced by previously charged particles collected on a filter inside a Faraday cage. The NanoTracer is able to evaluate the different fractions (alveolar and tracheobronchial) of the lung deposited surface area through a semi-empiric algorithm implemented by Marra et al. (2010) [61]. These personal monitors are equipped with an internal rechargeable lithium-ion battery, which allows them to be used during outdoor trips. The total run time (single battery charge) is about $7 \mathrm{~h}$. The counters were calibrated at the beginning of the experimental campaign in order to allow data quality assurance by comparison with a Nanoparticle Surface Area Monitor (NSAM, TSI Model 3550) to assess the human lung deposited surface area of particles corresponding to tracheobronchial (TB) and alveolar (Alv) regions of the lung. The temporal resolution of the NanoTracers was set to $16 \mathrm{~s}$ (advance mode).

Each adult kept the NanoTracer device for 24-h, carrying it with them in all of the microenvironments where they usually go during their normal life. Adults were asked to take notes about places visited, and start and end times of each activity. In particular, they were asked to record a note during each smoking event, indicating the start/end of smoking, and the relative environment/activity associated with the smoking event.

In order to detect the level of "free-smoke" particle background, the second Nanotracer was used. In particular, during smoking events, the second device was put on in separate (free-smoke) environments in close vicinity of the smoker.

Based on the time duration of each activity performed by smokers, the average particle deposited alveolar and tracheobronchial surface area concentrations were calculated and were representative of smoker adults' exposure to SHS, whilst the average particle deposited alveolar and tracheobronchial surface area concentrations were calculated based on data from the second Nanotracer device and were representative of "free-smoke" particle background.

From data of 24-h exposure of smoker adults, and data of "free-smoke" background, we calculated the extra-dose due to the smoking activity as the increase of the particle dose received by smokers with respect to the background. Therefore, the extra dose result was not affected by the ambient concentration which, conversely, was included in the "free-smoke" background contribution (B). 


\subsubsection{Particle (Alveolar and Tracheobronchial) Deposited Doses in the SHS and B}

The partial dose (in terms of particle alveolar and tracheobronchial deposited surface area concentration) received by adults in each microenvironment/activity was determined by multiplying the alveolar and tracheobronchial surface area $\left(\mathrm{S}_{\mathrm{Alv}, \mathrm{TB}}\right)$ for the time spent $(\mathrm{T})$ in the $j$-th microenvironment and the inhalation rate ( $\left.\mathbb{I R}_{\text {activity }}\right)$ corresponding to the activity carried out [62]. Then, we added the partial doses to estimate the daily total deposited alveolar and tracheobronchial

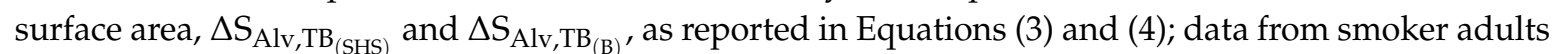
are representative of daily particle dose obtained as the sum of the dose related to the secondhand smoke aerosol generated by cigarettes and that related to the "free smoke" particle background of the specific environment. Therefore, data from the "free smoke" particle background are representative of particle dose received by non-smoker adults in the same environment.

$$
\begin{aligned}
\Delta \mathrm{S}^{\prime}{ }_{\mathrm{Alv}, \mathrm{TB}_{(\mathrm{SHS})}} & =\sum_{\mathrm{j}=1}^{\mathrm{n}} \mathrm{S}_{\mathrm{Alv}, \mathrm{TB}} \cdot \mathrm{T} \cdot \mathrm{IR}_{\text {activity }} \\
\Delta \mathrm{S}_{\mathrm{Alv}, \mathrm{TB}}(\mathrm{B}) & =\sum_{\mathrm{j}=1}^{\mathrm{n}} \mathrm{S}_{\mathrm{Alv}, \mathrm{TB}} \cdot \mathrm{T} \cdot \mathrm{IR}_{\text {activity }}
\end{aligned}
$$

In the above reported equations $\mathrm{S}_{\mathrm{Alv}, \mathrm{TB}}$ is the alveolar and tracheobronchial particle deposited surface area concentration $\left(\mu \mathrm{m}^{2} \cdot \mathrm{cm}^{-3}\right), \mathrm{T}$ is the time spent in the three environments $(\mathrm{h})$, and $\mathrm{IR}_{\text {activity }}$ is the inhalation rate $\left(\mathrm{m}^{3} \cdot \mathrm{h}^{-1}\right)$. Inhalation rates for the different activities were adopted on the basis of the United States Environmental Protection Agency, (US EPA) approach [63], ranging from $0.3 \mathrm{~m}^{3} \cdot \mathrm{h}^{-1}$ during sleeping and resting to $1.4 \mathrm{~m}^{3} \cdot \mathrm{h}^{-1}$ during sporting activities.

In order to isolate the effect of the secondhand smoke aerosol generated by cigarettes, we calculated the normalized increase of the particle dose, per single cigarette received by smokers, with respect to the "free smoke" particle background. Then, multiplying the normalized increase of particle dose per the average number of cigarettes per day (13 cigarette/day), we calculated the daily extra dose. Therefore, the extra dose $\left(\Delta \mathrm{S}_{\left.\mathrm{Alv}, \mathrm{TB}_{(\mathrm{SHS})}\right)}\right)$ is involved in the calculation of SHS aerosol on smokers and this resulting value was not affected by the ambient concentration which, conversely, was included in the "free-smoke" background contribution (B).

\section{Results and Discussion}

\subsection{Alveolar and Tracheobronchial Deposited Particle Surface Area Concentrations in the MSS}

The average (and standard deviation) values of deposited particle surface area concentrations (alveolar and tracheobronchial fractions) found in the mainstream aerosol of the investigated cigarettes were: $1.48 \times 10^{13} \mu \mathrm{m}^{2} \cdot \mathrm{cm}^{-3}$ and $4.56 \times 10^{12} \mu \mathrm{m}^{2} \cdot \mathrm{cm}^{-3}$ for male and $1.20 \times 10^{13} \mu \mathrm{m}^{2} \cdot \mathrm{cm}^{-3}$ and $5.18 \times 10^{12} \mu^{2} \cdot \mathrm{cm}^{-3}$ for female, respectively.

Alveolar deposited particle surface area concentrations were higher than tracheobronchial deposited ones for males and females. This is due to the lung deposition efficiency, which is known to be higher in the alveolar (Alv) than the tracheobronchial (TB) region $[57,64,65]$.

The lung deposited particle surface area concentrations at the mainstream, regardless of the deposition in the lung tract, are extremely higher than particle concentration levels which people are exposed to in typical indoor, outdoor, and occupational environments [49,56,66-72], thereby resulting in extremely high doses received by smokers as hereinafter reported.

The deposited particle surface area distributions found in the mainstream aerosol of the investigated cigarettes were reported in Figure 1 distinguishing between alveolar (Alv) and tracheobronchial (TB) deposition for males (Figure 1a) and females (Figure 1b). Alveolar and tracheobronchial deposited particle surface area distributions were similar for males and females. Unimodal distributions were found with a mode at $328 \mathrm{~nm}$. Such high values of deposited particle 
surface area concentrations in the MS of cigarettes are due to the great emission of sub-micron particles [41,73]. Sub-micron particles lead to this outstanding contribution of particles smaller than $1 \mu \mathrm{m}$ to the overall surface area distributions/concentrations.
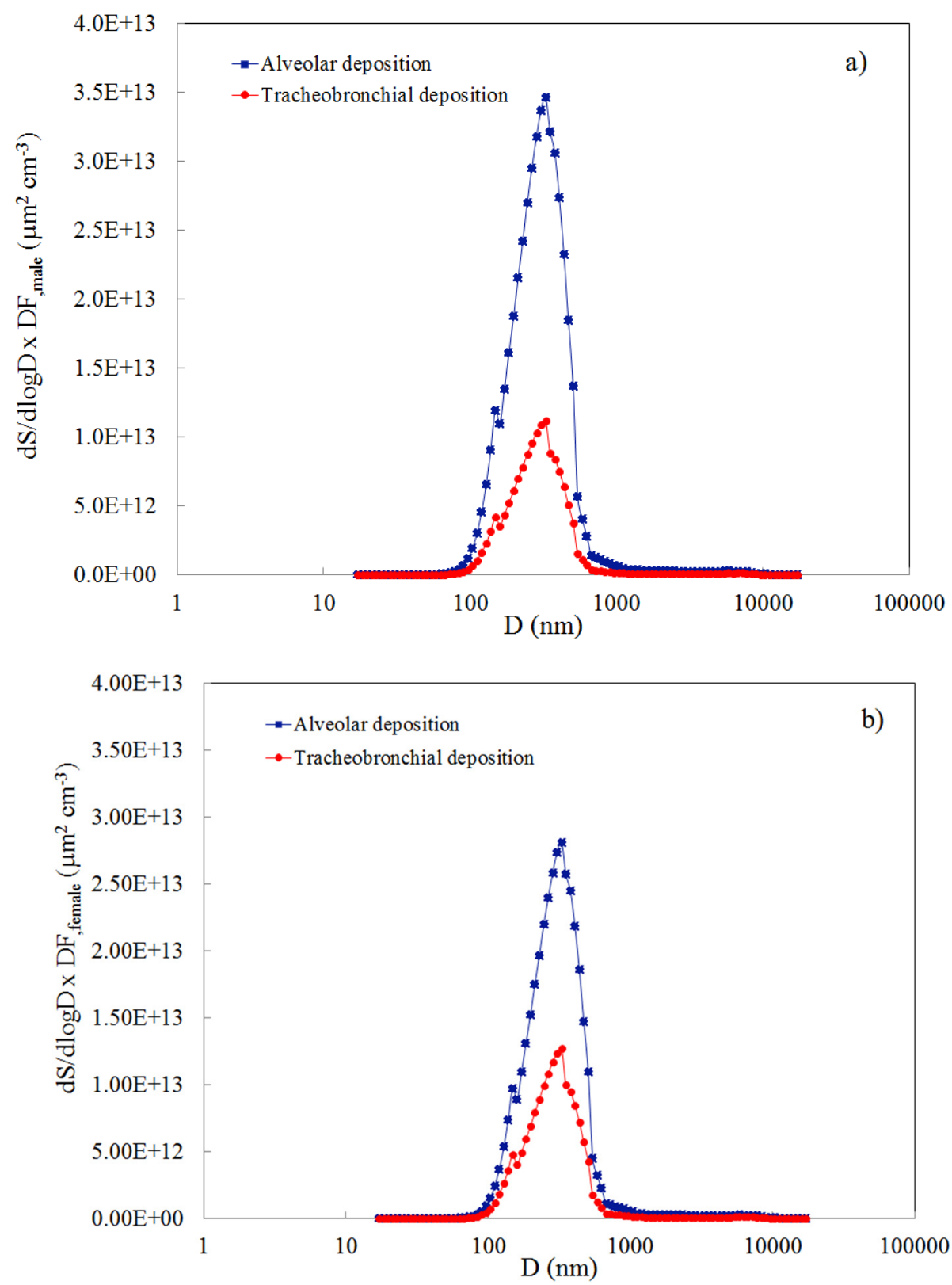

Figure 1. Deposited particle surface area distributions in the mainstream aerosol of the investigated cigarettes in terms of alveolar (Alv) and tracheobronchial (TB) deposition, for males (a) and females (b).

\subsection{Alveolar and Tracheobronchial Particle Dose in the MSS}

The daily doses calculated for typical adult Italian smokers (males and females), in terms of deposited particle surface area in the MSS, resulting from the Monte Carlo simulation and expressed as most probable values and 5th-95th intervals, are reported in Table 3. As expected, huge doses from the mainstream particle concentrations were measured, for both males and females, in terms of deposited surface area. Particle surface area doses (expressed as sum of alveolar and tracheobronchial fractions) were $1.13 \times 10^{5} \mathrm{~mm}^{2}$.day ${ }^{-1}$ and $8.85 \times 10^{4} \mathrm{~mm}^{2}$. day ${ }^{-1}$ for male and female smokers, respectively. These huge dose values are larger than the overall daily dose in terms of surface area received by 
the non-smoking Italian population [56,70], and even larger than those received by people in highly polluted indoor environments, such as kitchens [49].

Table 3. Particle surface area doses per day received by smokers in the MSS ("MPV" represents the most probable value of the dose, and 5th and 95th represent the 5th and 95th percentiles, respectively, of the dose values).

\begin{tabular}{|c|c|c|c|c|c|c|}
\hline & $\begin{array}{c}\Delta S_{A l v,(M S S)} F \\
\left(\mathrm{~mm}^{2} \cdot \text { Day }^{-1}\right)\end{array}$ & $\begin{array}{c}\Delta S_{T B_{,(M S S)}} F \\
\left(\mathrm{~mm}^{2} \cdot \text { Day }^{-1}\right)\end{array}$ & $\begin{array}{c}\Delta S_{A l v,(M S S)} M \\
\left(\mathrm{~mm}^{2} \cdot \mathrm{Day}^{-1}\right)\end{array}$ & $\begin{array}{c}\Delta S_{T B_{,(M S S)}} M \\
\left(\mathrm{~mm}^{2} \cdot \text { Day }^{-1}\right)\end{array}$ & $\begin{array}{c}\Delta S_{A l v+T B,(M S S)} F \\
\left(\mathrm{~mm}^{2} \cdot \mathrm{Day}^{-1}\right)\end{array}$ & $\begin{array}{c}\Delta S_{A l v+T B,(M S S)} M \\
\left(\mathrm{~mm}^{2} \cdot \mathrm{Day}^{-1}\right)\end{array}$ \\
\hline MPV & $6.17 \times 10^{4}$ & $2.87 \times 10^{4}$ & $7.96 \times 10^{4}$ & $2.70 \times 10^{4}$ & $8.85 \times 10^{4}$ & $1.13 \times 10^{5}$ \\
\hline 5 th & $2.69 \times 10^{4}$ & $1.29 \times 10^{4}$ & $2.01 \times 10^{4}$ & $1.19 \times 10^{4}$ & $4.68 \times 10^{4}$ & $4.46 \times 10^{4}$ \\
\hline 95th & $1.22 \times 10^{5}$ & $5.56 \times 10^{4}$ & $2.04 \times 10^{5}$ & $5.60 \times 10^{4}$ & $1.68 \times 10^{5}$ & $2.46 \times 10^{5}$ \\
\hline
\end{tabular}

\subsection{Alveolar and Tracheobronchial Particle Dose in the SHS and B}

The daily doses calculated for typical adult Italian smokers and non-smokers, in terms of deposited particle surface area, related to the extra dose due to the secondhand smoke aerosol (SHS) and the level of "free smoke" particle background (B), are reported in Table 4 as average value \pm standard deviation.

Table 4. Particle surface area doses per day received related to the extra dose due to secondhand smoke aerosol (SHS) and the level of "free smoke" particle background (B).

\begin{tabular}{|c|c|c|c|c|}
\hline Sampler & $\begin{array}{c}\text { Type of } \\
\text { Measurement }\end{array}$ & Micro-Environment & $\begin{array}{c}\Delta S_{A l v_{(S H S, B)}} \\
\left(\mathrm{mm}^{2} \cdot \text { Day }^{-1}\right)\end{array}$ & $\begin{array}{c}\Delta S_{T B_{(S H S, B)}} \\
\left(\mathrm{mm}^{2} \cdot \text { Day }^{-1}\right)\end{array}$ \\
\hline (As non-smoker) & $\begin{array}{l}\text { "Free smoke" } \\
\text { background }\end{array}$ & & $3.72 \pm 1.08 \times 10^{2}$ & $7.51 \pm 2.16 \times 10^{1}$ \\
\hline Smoker & $\begin{array}{l}\text { Secondhand } \\
\text { smoke aerosol }\end{array}$ & $\begin{array}{l}\text { Outdoor/urban city } \\
\text { Indoor/home } \\
\text { Transportation/car }\end{array}$ & $\begin{array}{l}4.70 \pm 3.85 \times 10^{2} \\
6.80 \pm 1.81 \times 10^{2} \\
1.61 \pm 0.51 \times 10^{3}\end{array}$ & $\begin{array}{l}9.47 \pm 7.84 \times 10^{1} \\
1.38 \pm 0.36 \times 10^{2} \\
3.26 \pm 1.04 \times 10^{2}\end{array}$ \\
\hline
\end{tabular}

The average daily particle doses received in the secondhand smoke aerosol by smokers $\left(9.21 \pm 3.57 \times 10^{2} \mathrm{~mm}^{2} \cdot\right.$ day $^{-1}$ and $1.86 \pm 0.73 \times 10^{2} \mathrm{~mm}^{2} \cdot$ day $^{-1}$, for alveolar and tracheobronchial fraction, respectively) were one order of magnitude larger than those found at the "free-smoke" particle background level $\left(3.72 \pm 1.08 \times 10^{2} \mathrm{~mm}^{2} \cdot\right.$ day $^{-1}$ and $7.51 \pm 2.16 \times 10^{1} \mathrm{~mm}^{2} \cdot$ day $^{-1}$, for alveolar and tracheobronchial fractions, respectively).

Values of daily dose received by smokers due to SHS aerosol are comparable to the overall daily dose received by Italian children $\left(1.92-0.60 \times 10^{3} \mathrm{~mm}^{2} \cdot \mathrm{day}^{-1}\right)$ [74] while daily dose found at the "free-smoke" particle background level could be comparable to the overall daily dose received by Australian children [75,76].

The dose contribution of the "free-smoke" particle background showed the overexposure due to smoking activities. Such doses depended on the time activity pattern of the population under investigation.

Daily particle doses detected from the secondhand smoke aerosol were found to be affected by the specific micro-environments visited by smokers, ranging between $4.70 \pm 3.85 \times 10^{2}$ for outdoor environments and $1.61 \pm 0.51 \times 10^{3} \mathrm{~mm}^{2}$. day ${ }^{-1}$ during transportation. Smoking outdoors was found to be slightly less impactful on daily SHS dose compared to smoking indoors.

However, these values seemed to be lower than typical daily dose values found in previous studies as, for example, values higher than $2 \times 10^{3} \mathrm{~mm}^{2}$. day ${ }^{-1}$ were found by Buonanno et al. (2012) [70]. This could be attributed to the selected population of this study, since students are typically less exposed to cooking- generated particles, which are known to highly affect daily particle exposure. Moreover, data from this paper could be affected by the seasonal period in which the experimental campaign was carried out (i.e., during spring). In fact, during summer time, particle exposure levels are lower than those that occur during winter time due to higher ventilation conditions $[67,71]$. 


\subsection{Daily Alveolar and Tracheobronchial Deposited Dose for a Typical Smoker}

In order to calculate the total daily deposited (total of alveolar and tracheobronchial fractions) particle surface area dose for a typical smoker, the authors evaluated and considered the contribution of MSS, SHS, and "free-smoke" particle background. Considering that: (i) the average value between the most probable values of dose found in the MSS for male and female was $1.01 \times 10^{5} \mathrm{~mm}^{2} \cdot \mathrm{day}^{-1}$; (ii) the sum of average values of the tracheobronchial and alveolar dose found from SHS was $1.11 \times 10^{3} \mathrm{~mm}^{2} \cdot \mathrm{day}^{-1}$, and (iii) the sum of the tracheobronchial and alveolar dose found from $\mathrm{B}$ was $4.47 \times 10^{2} \mathrm{~mm}^{2}$. day ${ }^{-1}$, the total daily deposited dose in terms of particle surface area for typical Italian smokers was $1.03 \times 10^{5} \mathrm{~mm}^{2} \cdot$ day $^{-1}$.

The highest contribution to the daily dose was from the MSS with $98.5 \%$, SHS was observed to contribute $1.1 \%$, with contributions increasing up to $2 \%$ if the smoker was smoking while travelling by car.

\section{Conclusions}

This paper provides an evaluation of the overall dose received by smokers which is the sum of three contributions: i.e., mainstream aerosol directly inhaled by the smoker, secondhand smoke produced by the smoker himself and then inhaled, and the background dose typical of a non-smoker.

The dose due to the mainstream aerosol was evaluated by measuring the particle concentration at the mainstream smoke while the dose contribution of the secondhand smoke and of the background level was evaluated through particle concentration exposure at a personal scale. For this analysis, the dose contribution of the background level was important in order to show the overexposure due to smoking activities.

High values of lung deposited particle surface area concentrations were found in the mainstream aerosol of the investigated cigarettes due to the great emission of sub-micron particles

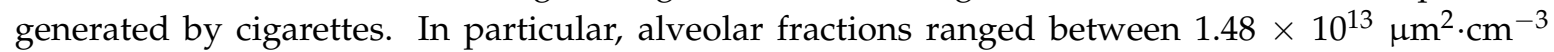
for males and $1.20 \times 10^{13} \mu^{2} \cdot \mathrm{cm}^{-3}$ for females, while tracheobronchial fractions ranged between $4.56 \times 10^{12} \mu \mathrm{m}^{2} \cdot \mathrm{cm}^{-3}$ for males and $5.18 \times 10^{12} \mu^{2} \cdot \mathrm{cm}^{-3}$ for females. Unimodal distributions were found in terms of the deposited particle surface area for males and females with a mode at $328 \mathrm{~nm}$.

In terms of particle surface area doses, due to the mainstream smoke aerosol, huge values were found: $1.13 \times 10^{5} \mathrm{~mm}^{2}$. day ${ }^{-1}$ for males and $8.85 \times 10^{4} \mathrm{~mm}^{2}$. day ${ }^{-1}$ for females.

Particle doses received by smokers due to the secondhand smoke aerosol were $1.11 \times 10^{3} \mathrm{~mm}^{2} \cdot$ day $^{-1}$, while lower values were attributed to the "free-smoke" particle background $\left(4.47 \times 10^{2} \mathrm{~mm}^{2} \cdot\right.$ day $\left.^{-1}\right)$.

This paper found that the total daily deposited dose in terms of particle surface area for typical Italian smokers was $1.03 \times 10^{5} \mathrm{~mm}^{2}$. day ${ }^{-1}$.

The greater contribution to this huge value of daily dose was addressable to the mainstream smoke-particles generated ( $98 \%$ ) while SHS contributed to $1.1 \%$, increasing up to $2 \%$ if the smoker was smoking while travelling in a car.

The authors point out that for the very first time a complete analysis of the overall dose received by smokers was carried out, as the sum of three contributions: i.e., mainstream aerosol directly inhaled by the smoker, secondhand smoke produced by the smoker himself and then inhaled, and the background dose typical of a non-smoker. Results of this paper could be useful for lung cancer risk model analysis on the Italian smoking population.

Author Contributions: Fernanda Carmen Fuoco: experimental campaign, analysis of the data, and manuscript writing; Luca Stabile: experimental campaign, analysis of the data, and manuscript writing; Giorgio Buonanno: scientific supervisor of the experimental campaign and data interpretation; Mauro Scungio: data treatment and manuscript writing; Maurizio Manigrasso: data treatment and manuscript writing; Andrea Frattolillo: data interpretation and manuscript writing.

Conflicts of Interest: The authors declare no conflict of interest. 


\section{References}

1. Unfried, K.; Albrecht, C.; Klotz, L.O.; Mikecz, A.V.; Grether-Beck, S.; Schins, R.P.F. Cellular responses to nanoparticles: Target structures and mechanisms. Nanotoxicology 2007, 1, 52-71. [CrossRef]

2. Schins, R.P.; Lightbody, J.H.; Borm, P.J.; Shi, T.; Donaldson, K.; Stone, V. Inflammatory effects of coarse and fine particulate matter in relation to chemical and biological constituents. Toxicol. Appl. Pharmacol. 2004, 195, 1-11. [CrossRef] [PubMed]

3. Weichenthal, S. Selected physiological effects of ultrafine particles in acute cardiovascular morbidity. Environ. Res. 2012, 115, 26-36. [CrossRef] [PubMed]

4. Semmler, M.; Seitz, J.; Erbe, F.; Mayer, P.; Heyder, J.; Oberdorster, G. Long-term clearance kinetics of inhaled ultrafine insoluble iridium particles from the rat lung, including transient translocation into secondary organs. Inhal. Toxicol. 2004, 16, 453-459. [CrossRef] [PubMed]

5. Calderon-Garciduenas, L.; Reed, W.; Maronpot, R.R.; Henriquez-Roldan, C.; Delgado-Chavez, R.; Calderon-Garciduenas, A. Brain inflammation and Alzheimer's like pathology in individuals exposed to severe air pollution. Toxicol. Pathol. 2004, 32, 650-658. [CrossRef] [PubMed]

6. Brown, D.M.; Wilson, M.R.; MacNee, W.; Stone, V.; Donaldson, K. Size dependent proinflammatory effects of ultrafine polystyrene particles: A role for surface area and oxidative stress in the enhanced activity of ultrafines. Toxicol. Appl. Pharmacol. 2001, 175, 191-199. [CrossRef] [PubMed]

7. Nygaard, U.C.; Samuelsen, M.; Aase, A.; Lovik, M. The capacity of particles to increase allergic sensitization is predicted by particle number and surface area, not by particle mass. Toxicol. Sci. 2004, 82, 515-524. [CrossRef] [PubMed]

8. Schmid, O.; Moller, W.; Semmler-Behnke, M.; Ferron, G.A.; Karg, E.; Lipka, J.; Shulz, H.; Kreyling, W.G.; Stoeger, T. Dosimetry and toxicology of inhaled ultrafine particles. Biomarkers 2009, 14 (Suppl. S1), 67-73. [CrossRef] [PubMed]

9. Buonanno, G.; Marks, G.B.; Morawska, L. Health effects of daily airborne particle dose in children: direct association between personal dose and respiratory health effects. Environ. Pollut. 2013, 180, 246-250. [CrossRef] [PubMed]

10. International Agency for Research on Cancer. IARC Monographs on the Evaluation of carcinogenic Risks to Humans; International Agency for Research on Cancer: Lyon, France, 2004.

11. American Cancer Society. Cancer Facts \& Figures 2014; American Cancer Society: Atlanta, GA, USA, 2014.

12. U.S. Department of Health and Human Services. How Tobacco Smoke Causes Disease: The Biology and Behavioral Basis for Smoking-Attributable Disease: A Report of the Surgeon General. In Nicotine Addiction: Past and Present; Centers for Disease Control and Prevention (US), National Center for Chronic Disease Prevention and Health Promotion (US), Office on Smoking and Health (US), Centers for Disease Control and Prevention (US): Atlanta, GA, USA, 2010.

13. U.S. Department of Health and Human Services. The Health Consequences of Smoking-50 Years of Progress: A Report of the Surgeon General; U.S. Department of Health and Human Services: Atlanta, GA, USA, 2014.

14. Pesch, B.; Kendzia, B.; Gustavsson, P.; Jockel, K.H.; Johnen, G.; Pohlabeln, H.; Olsson, A.; Ahrens, W.; Gross, I.M.; Bruske, I.; et al. Cigarette smoking and lung cancer-Relative risk estimates for the major histological types from a pooled analysis of case-control studies. Int. J. Cancer 2012, 131, 1210-1219. [CrossRef] [PubMed]

15. Simonato, L.; Agudo, A.; Ahrens, W.; Benhamou, E.; Benhamou, S.; Boffetta, P.; Brennan, P.; Darby, S.C.; Forastiere, F.; Fortes, C.; et al. Lung cancer and cigarette smoking in Europe: An update of risk estimates and an assessment of inter-country heterogeneity. Int. J. Cancer 2001, 91, 876-887. [CrossRef]

16. Doll, R.; Peto, R. The causes of cancer: Quantitative estimates of avoidable risks of cancer in the United States today. J. Natl. Cancer Inst. 1981, 66, 1191-1308. [PubMed]

17. Doll, R.; Peto, R.; Boreham, J.; Sutherland, I. Mortality in relation to smoking: 50 years' observations on male British doctors. Br. Med. J. 2004, 328, 15-19. [CrossRef] [PubMed]

18. Mong, C.; Garon, E.B.; Fuller, C.; Mahtabifard, A.; Mirocha, J.; Mosenifar, Z.; McKenna, R. High prevalence of lung cancer in a surgical cohort of lung cancer patients a decade after smoking cessation. J. Cardiothorac. Surg. 2011, 25, 6-19. [CrossRef] [PubMed] 
19. Peto, R.; Darby, S.; Deo, H.; Silcocks, P.; Whitley, E.; Doll, R. Smoking, smoking cessation, and lung cancer in the UK since 1950: Combination of national statistics with two case-control studies. Br. Med. J. 2000, 321, 323-329. [CrossRef]

20. Kralikova, E. Lung cancer and smoking. Lung Cancer 2012, 77 (Suppl. S1), S7-S8. [CrossRef]

21. Yu, Y.; Liu, H.; Zheng, S.; Ding, Z.; Chen, Z.; Jin, W.; Wang, L.; Wang, Z.; Fei, Y.; Zhang, S.; et al. Gender susceptibility for cigarette smoking-attributable lung cancer: A systematic review and meta-analysis. Lung Cancer 2014, 85, 351-360. [CrossRef] [PubMed]

22. Forastiere, F.; Perucci, C.A.; Arca, M.; Axelson, O. Indirect estimates of lung cancer death rates in Italy not attributable to active smoking. Epidemiology 1993, 4, 502-510. [CrossRef] [PubMed]

23. Crawford, T.V.; McGrowder, D.A.; Barnett, J.D.; McGaw, B.A.; McKenzie, I.F.; James, L.G. Tobacco-related chronic illnesses: A public health concern for Jamaica. Asian Pac. J. Cancer Prev. 2012, 13, 4733-4738. [CrossRef] [PubMed]

24. Ding, Y.S.; Trommel, J.S.; Yan, X.J.; Ashley, D.; Watson, C.H. Determination of 14 polycyclic aromatic hydrocarbons in mainstream smoke from domestic cigarettes. Environ. Sci. Technol. 2005, 39, 471-478. [CrossRef] [PubMed]

25. Ding, Y.S.; Ward, J.; Hammond, D.; Watson, C.H. Mouth-level intake of benzo[a]pyrene from reduced nicotine cigarettes. Int. J. Environ. Res. Public Health 2014, 11, 11898-11914. [CrossRef] [PubMed]

26. Morton, M.J.; Laffoon, S.W. Cigarette smoke chemistry market maps under Massachusetts Department of Public Health smoking conditions. Regul. Toxicol. Pharmacol. 2008, 51, 1-30. [CrossRef] [PubMed]

27. Vu, A.T.; Taylor, K.M.; Holman, M.R.; Ding, Y.S.; Hearn, B.; Watson, C.H. Polycyclic Aromatic Hydrocarbons in the Mainstream Smoke of Popular U.S. Cigarettes. Chem. Res. Toxicol. 2015, 28, 1616-1626. [CrossRef] [PubMed]

28. Wilson, C.L.; Bodnar, J.A.; Brown, B.G.; Morgan, W.T.; Potts, R.J.; Borgerding, M.F. Assessment of dioxin and dioxin-like compounds in mainstream smoke from selected US cigarette brands and reference cigarettes. Food Chem. Toxicol. 2008, 46, 1721-1733. [CrossRef] [PubMed]

29. Ashraf, M.W. Levels of heavy metals in popular cigarette brands and exposure to these metals via smoking. Sci. World J. 2012, 2012, 729430. [CrossRef] [PubMed]

30. Counts, M.E.; Hsu, F.S.; Laffoon, S.W.; Dwyer, R.W.; Cox, R.H. Mainstream smoke constituent yields and predicting relationships from a worldwide market sample of cigarette brands: ISO smoking conditions. Regul. Toxicol. Pharmacol. 2004, 39, 111-134. [CrossRef] [PubMed]

31. Counts, M.E.; Morton, M.J.; Laffoon, S.W.; Cox, R.H.; Lipowicz, P.J. Smoke composition and predicting relationships for international commercial cigarettes smoked with three machine-smoking conditions. Regul. Toxicol. Pharmacol. 2005, 41, 185-227. [CrossRef] [PubMed]

32. Kazi, T.G.; Jalbani, N.; Arain, M.B.; Jamali, M.K.; Afridi, H.I.; Sarfraz, R.A.; Shah, A.Q. Toxic metals distribution in different components of Pakistani and imported cigarettes by electrothermal atomic absorption spectrometer. J. Hazard. Mater. 2009, 163, 302-307. [CrossRef] [PubMed]

33. Pappas, R.S.; Fresquez, M.R.; Martone, N.; Watson, C.H. Toxic metal concentrations in mainstream smoke from cigarettes available in the USA. J. Anal. Toxicol. 2014, 38, 204-211. [CrossRef] [PubMed]

34. Verma, S.; Yadav, S.; Singh, I. Trace metal concentration in different Indian tobacco products and related health implications. Food Chem. Toxicol. 2010, 48, 2291-2297. [CrossRef] [PubMed]

35. Roemer, E.; Stabbert, R.; Rustemeier, K.; Veltel, D.J.; Meisgen, T.J.; Reininghaus, W.; Carchman, R.A.; Gaworski, C.L.; Podraza, K.F. Chemical composition, cytotoxicity and mutagenicity of smoke from US commercial and reference cigarettes smoked under two sets of machine smoking conditions. Toxicology 2004, 195, 31-52. [CrossRef] [PubMed]

36. Stepanov, I.; Knezevich, A.; Zhang, L.; Watson, C.H.; Hatsukami, D.K.; Hecht, S.S. Carcinogenic tobacco-specific N-nitrosamines in US cigarettes: Three decades of remarkable neglect by the tobacco industry. Tob. Control 2012, 21, 44-48. [CrossRef] [PubMed]

37. Swauger, J.E.; Steichen, T.J.; Murphy, P.A.; Kinsler, S. An analysis of the mainstream smoke chemistry of samples of the U.S. cigarette market acquired between 1995 and 2000. Regul. Toxicol. Pharmacol. 2002, 35, 142-156. [CrossRef] [PubMed]

38. Adam, T.; McAughey, J.; McGrath, C.; Mocker, C.; Zimmermann, R. Simulta-neous online size and chemical analysis of gas phase and particulate phase of cigarette mainstream smoke. Anal. Bioanal. Chem. 2009, 394, 1193-1203. [CrossRef] [PubMed] 
39. Alderman, S.L.; Ingebrethsen, B.J. Characterization of mainstream cigarette smoke particle size distributions from commercial cigarettes using a DMS500 fast particulate spectrometer and smoking cycle simulator. Aerosol. Sci. Technol. 2011, 45, 1409-1421. [CrossRef]

40. Borgerding, M.; Klus, H. Analysis of complex mixtures e cigarette smoke. Exp. Toxicol. Pathol. 2005, 57 (Suppl. S1), 43-73. [CrossRef] [PubMed]

41. Fuoco, F.C.; Buonanno, G.; Stabile, L.; Vigo, P. Influence parameters of particle concentration and size distribution in the mainstream of e-cigarettes. Environ. Pollut. 2014, 184, 523-529. [CrossRef] [PubMed]

42. Golia, E.E.; Dimirkou, A.; Mitsios, I.K. Accumulation of Metals on Tobacco Leaves (Primings) Grown in an Agricultural Area in Relation to Soil. Bull. Environ. Contam. Toxicol. 2007, 79, 158-162. [CrossRef] [PubMed]

43. Loomis, D.; Grosse, Y.; Lauby-Secretan, B.; Ghissassi, F.E.; Bouvard, V.; Benbrahim-Tallaa, L.; Guha, N.; Baan, R.; Mattock, H.; Straif, K. The carcinogenicity of outdoor air pollution. Lancet Oncol. 2013, 14, 1262-1263. [CrossRef]

44. Golia, E.E.; Dimirkou, A.; Mitsios, I.K. Heavy-Metal Concentration in Tobacco Leaves in Relation to Their Available Soil Fractions. Commun. Soil Sci. Plant Anal. 2009, 40, 106-120. [CrossRef]

45. International Agency for Research on Cancer. Outdoor Air Pollution a Leading Environmental Cause of Cancer Deaths; WHO: Geneva, Switzerland, 2013.

46. Kane, D.B.; Asgharian, B.; Price, O.T.; Rostami, A.; Oldham, M.J. Effect of Smoking Parameters on the Particle Size Distribution and Predicted Airway Deposition of Main Stream Cigarette Smoke. Inhal. Toxicol. 2010, 22, 199-209. [CrossRef] [PubMed]

47. Valente, P.; Forastiere, F.; Bacosi, A.; Cattani, G.; Di Carlo, S.; Ferri, M.; Figà-Talamanca, I.; Marconi, A.; Paoletti, L.; Perucci, C.; et al. Exposure to fine and ultrafine particles from secondhand smoke in public places before and after the smoking ban, Italy 2005. Tob. Control 2007, 16, 312-317. [CrossRef] [PubMed]

48. Buonanno, G.; Marini, S.; Morawska, L.; Fuoco, F.C. Individual dose and exposure of Italian children to ultrafine particles. Sci. Total Environ. 2012, 438, 271-277. [CrossRef] [PubMed]

49. Stabile, L.; Fuoco, F.C.; Marini, S.; Buonanno, G. Effects of the exposure to indoor cooking-generated particles on nitric oxide exhaled by women. Atmos. Environ. 2015, 103, 238-246. [CrossRef]

50. Hueglin, C.; Scherrer, L.; Burtscher, H. An accurate, continuously adjustable dilution system (1:10 to 1:104) for submicron aerosols. J. Aerosol Sci. 1997, 28, 1049-1055. [CrossRef]

51. Burtscher, H. Physical characterization of particulate emissions from diesel engines: A review. J. Aerosol Sci. 2005, 36, 896-932. [CrossRef]

52. Buonanno, G.; Scungio, M.; Stabile, L.; Tirler, W. Ultrafine particle emission from incinerators: The role of the fabric filter. J. Air Waste Manag. Assoc. 2012, 62, 103-111. [CrossRef] [PubMed]

53. Shen, S.; Jaques, P.A.; Zhu, Y.; Geller, M.D.; Sioutas, C. Evaluation of the SMPS-APS system as a continuous monitor for measuring $\mathrm{PM}_{2.5}, \mathrm{PM}_{10}$ and coarse $\left(\mathrm{PM}_{2.5-10}\right)$ concentrations. Atmos. Environ. 2002, 36, 3939-3950. [CrossRef]

54. Johnson, T.J.; Olfert, J.S.; Cabot, R.; Treacy, C.; Yurteri, C.U.; Dickens, C.; McAughey, J.; Symonds, J.P.R. Steady-state measurement of the effective particle density of cigarette smoke. J. Aerosol Sci. 2014, 75, 9-16. [CrossRef]

55. Buonanno, G.; Giovinco, G.; Morawska, L.; Stabile, L. Tracheobronchial and alveolar dose of submicrometer particles for different population age groups in Italy. Atmos. Environ. 2011, 45, 6216-6224. [CrossRef]

56. Buonanno, G.; Giovinco, G.; Morawska, L.; Wang, L. Submicrometer Particle Dose for Different Population Age Groups in Brisbane, Australia. In Proceedings of Metrology Society of Australia Conference, Geelong, Australia, 19-21 October 2011.

57. International Commission on Radiological Protection. Human respiratory tract model for radiological protection. A report of a Task Group of the International Commission on Radiological Protecton. Ann. ICRP 1994, 24, 1-482.

58. Istituto Superiore di Sanità. Il Fumo in Italia. "In Indagini DOXA". 2015. Available online: http:/ /www.iss. it/fumo/index.php?lang=1\&id=350\&tipo=18 (accessed on 16 January 2016).

59. Zacny, J.P.; Stitzer, M.L. Human Smoking Patterns, in: Monograph 7: The FTC Cigarette Test Method for Detemining Tar, Nicotine, and Carbon Monoxide Yields of U.S.; Cigarettes National Cancer Institute: Washington, DC, USA, 1988.

60. Hammersley, J.M.; Handscomb, D.C. Monte Carlo Methods; Chapman and Hall: London, UK; New York, NY, USA, 1964. 
61. Marra, J.; Voetz, M.; Kiesling, H.J. Monitor for detecting and assessing exposure to airborne nanoparticles. J. Nanopart. Res. 2010, 12, 21-37. [CrossRef]

62. Klepeis, N.E. Modeling Human Exposure to Air Pollution. Human Exposure Analysis; CRC Press: Stanford, CA, USA, 2006; pp. 1-18.

63. US Environmental Protection Agency (US EPA). Air Quality Criteria for Particulate Matter (Final Report, Oct 2004) (No. EPA 600/P-99/002aF-bF); US EPA: Washington, DC, USA, 2004.

64. Oberdörster, G.; Sharp, Z.; Atudorei, V.; Elder, A.; Gelein, R.; Kreyling, W.; Cox, C. Translocation of inhaled ultrafine particles to the brain. Inhal. Toxicol. 2004, 16, 437-445. [CrossRef] [PubMed]

65. Cheng, Y.S.; Yeh, H.C.; Guilmette, R.A.; Simpson, S.Q.; Cheng, K.H.; Swift, D.L. Nasal Deposition of ultrafine particles in human volunteers and its relationship to airway geometry. Aerosol Sci. Technol. 1996, 25, $274-291$. [CrossRef]

66. Scungio, M.; Buonanno, G.; Arpino, F.; Ficco, G. Influential parameters on ultrafine particle concentrations downwind at waste-to-energy plants. Waste Manag. 2015, 38, 157-163. [CrossRef] [PubMed]

67. Buonanno, G.; Fuoco, F.C.; Stabile, L. Influential parameters on particle exposure of pedestrians in urban microenvironments. Atmos. Environ. 2011, 45, 1434-1443. [CrossRef]

68. Buonanno, G.; Morawska, L.; Stabile, L. Exposure to welding particles in automotive plants. J. Aerosol Sci. 2011, 42, 295-304. [CrossRef]

69. Buonanno, G.; Morawska, L.; Stabile, L.; Viola, A. Exposure to particle number, surface area and PM concentrations in pizzerias. Atmos. Environ. 2010, 44, 3963-3969. [CrossRef]

70. Buonanno, G.; Morawska, L.; Stabile, L.; Wang, L.; Giovinco, G. A comparison of submicrometer particle dose between Australian and Italian people. Environ. Pollut. 2012, 169, 183-189. [CrossRef] [PubMed]

71. Fuoco, F.C.; Stabile, L.; Buonanno, G.; Trassiera, C.; Massimo, A.; Russi, A.; Mazaheri, M.; Morawska, L.; Andrade, A. Indoor Air Quality in Naturally Ventilated Italian Classrooms. Atmosphere 2015, 6, 1652-1675. [CrossRef]

72. Stabile, L.; Dell'Isola, M.; Frattolillo, A.; Massimo, A.; Russi, A. Effect of natural ventilation and manual airing on indoor air quality in naturally ventilated Italian classrooms. Build. Environ. 2016, 98, 180-189. [CrossRef]

73. Sahu, S.K.; Tiwari, M.; Bhangare, R.C.; Pandit, G.G. Particle size distribution of mainstream and exhaled cigarette smoke and predictive deposition in human respiratory tract. Aerosol Air Qual. Res. 2013, 13, 324-332. [CrossRef]

74. Buonanno, G.; Fuoco, F.C.; Morawska, L.; Stabile, L. Airborne particle concentrations at schools measured at different spatial scales. Atmos. Environ. 2013, 67, 38-45. [CrossRef]

75. Buonanno, G.; Dell'Isola, M.; Stabile, L.; Viola, A. Critical aspects of the uncertainty budget in the gravimetric PM measurements. Measurement 2011, 44, 139-147. [CrossRef]

76. Mazaheri, M.; Clifford, S.; Jayaratne, R.; Megat Mokhtar, M.A.; Fuoco, F.C.; Buonanno, G.; Morawska, L. School children's personal exposure to ultrafine particles in the urban environment. Environ. Sci. Technol. 2014, 48, 113-120. [CrossRef] [PubMed]

(c) 2017 by the authors; licensee MDPI, Basel, Switzerland. This article is an open access article distributed under the terms and conditions of the Creative Commons Attribution (CC BY) license (http:/ / creativecommons.org/licenses/by/4.0/). 